Коротков Дмитро Сергійович

кандидат політичних наук, доцент,

Харківський національний економічний університет

імені Семена Кузнеия,

Харків, Украӥна,

Kordis@meta.ua

\title{
ФЕНОМЕН ВІЙНИ В КОНТЕКСТІ ДЕМОКРАТИЧНОЇ ПАРАДИГМИ
}

Метою статті є дослідження основних принципів і концептуальних підходів дефініцій «війна» та аналіз сучасного змісту цього явища. Методологічною основою наукового дослідження $\epsilon$ діалектичний метод, на основі якого проаналізовано наукові уявлення про сутність та закономірності феномену війни та іiї вплив на формування цінностей і рівень захисту прав людини у демократичному суспільстві. Виявлено, що завдяки інформаційній революції світ змінюється, але це ніяк не впливає на кількість і якість конфліктів у світі. У контексті теорії міжнародних відносин ведуться пошуки рішення цієї проблеми. Теоретичним підгрунтям для демократичних країн $\epsilon$ теорія демократичного миру. 3'ясовано, що у демократичних країн $\epsilon$ чотири причини уникати війн, але мова йдеться про мирні взаємовідносини саме тільки між демократичними країнами. Оцінено вплив теорії справедливої війни на сучасну теорію демократичного миру стосовно змісту такого явища як війна.

Ключові слова: війна, демократичні цінності, право, мораль, справедлива війна, теорія демократичного миру.

Korotkov Dmytro, Candidate of Political Sciences, Associate Professor, Kharkiv National Economic University named after Semen Kuznets, Kharkiv, Ukraine

The war phenomenon in the democratic paradigm

The purpose of article is the research basic principles and conceptual approaches definitions of "war" and the analysis of the present content of the phenomenon. The methodological basis of scientific research is the dialectical method, based on analysis of scientific understanding of essence and the regularity of the phenomenon of war and its impact on the formation of values and protection of human rights in a democratic society. The information revolution changes the world. It does not affect the quantity and quality of conflicts in the world. In the context of international relations theory how to solve this problem were searched. The theoretical basis for democratic countries is the theory of democratic peace. It was found that in democracies there are four reasons to avoid war. But we are talking about peaceful relationship only between democracies countries. The influence of the theory of just war theory to modern democratic peace on the content of the phenomenon of war was evaluated.

Key words: war, democratic values, law, morality, fair war, theory of democratic peace.

Коротков Дмитрий Сергеевич, кандидат политических наук, дочент, Харьковский национальный экономический университет им. Семена Кузнеияа, Харьков, Украина

\section{Феномен войны в контексте демократической парадигмы}

Целью написания статьи является исследование основных принципов и концептуальных подходов дефиниций «война» и анализ современного содержания этого явления. Методологической основой научного исследования являются: диалектический метод, в основе которого проанализированы научные представления о сущности и закономерности феномена войны и ее влияние на формирование ценностей и уровень защиты прав человека в демократическом обществе. Выявлено, что благодаря информационной революции мир меняется, но это никак не влияет на количество и качество конфликтов в мире. В контексте теории международных отношений ведутся поиски решения этой проблемы. Теоретическим основанием 
для демократических стран является теория демократического мира. Установлено, что в демократических странах есть четыре причины избегать войн, но речь идет о мирных взаимоотношения именно только между демократическими странами. Оценено влияние теории справедливой войны на современную теорию демократического мира относительно содержания такого явления как война.

Ключевые слова: война, демократические ценности, право, мораль, справедливая война, теория демократического мира.

Вступ. Після розпаду СРСР та завершення «холодної» війни геополітична картина світу та сутність міжнародних відносин суттєво змінилися. Кінець тоталітаризму (його центру) в Свропі ознаменувався перемогою демократичної моделі розвитку суспільства, до якої повинні були прагнути і колишні країни з комуністичного табору. У той час перспективною і актуальною була теорія Ф. Фукуями «Кінець історії», яка стверджувала, що ми є свідками не просто кінця холодної війни або чергового періоду післявоєнної історії, але кінця історії як такої, завершення ідеологічної еволюції людства і універсалізації західної ліберальної демократії як остаточної форми правління [5, с. 136]. Чи означає перемога ліберальної демократії кінець конфліктам і війнам у світовому просторі - це актуальне питання у сучасних міжнародних відносинах. Стратегічною метою України $\epsilon$ інтеграція в європейський демократичний простір, але ми і знаходимося в стані «гібридної» війни з Росією. Викликом для нашої держави є одночасне вирішення цих процесів і проблем у контексті загальновідомої парадигми, що демократії одна 3 одною не воюють.

Аналіз попередніх досліджень і публікацій. Сучасне розуміння війни та миру базується у демократичних країнах на теоріях справедливої війни та демократичного миру. Дослідженням проблеми справедливих і несправедливих війн вчені займаються з давніх часів. На попередніх етапах історії розробниками відповідної теорії були Цицерон, Августин, Фома Аквінський, Гуго Гроцій, Еразм Роттердамський, I. Кант. Серед сучасних дослідників морального аспекту війни виділяються Дж. Ролз, М. Уолцер, Р. Риган, Р. Апресян та ін. Найактивніше засуджували війну та ставили під сумнів іiі здатність відповідати принципам справедливості Х.-Б. Альберді, Б. Рассел, Е. Тоффлер та ін. Засновником теорії демократичного світу прийнято вважати великого німецького філософа I. Канта. Надалі втілювати його ідеї продовжили М. Дойл, Б. Рассет, М. Хаас, М. Салливен та ін. Серед українських дослідників необхідно виділити праці Н. Аманмирадова, Т. Герасимчук, В. Лісіцина, І. Панафіліна, Ю. Ткаченко та ін.

Метою і завданням даного дослідження $є$ аналіз взаємозалежності та проблем таких явищ як війна і мир та методи подолання військового конфлікту в контексті демократичної парадигми.

Викладення матеріалу дослідження. Необхідно підкреслити, що нова парадигма міжнародних відносин формується вже як демократична, відкрита, системна і гуманістична. I хоча в різних регіонах світу виникають ті чи інші конфлікти, фактом залишається загальне прагнення людства до реалізації демократії, миротворчості, взаєморозуміння і толерантності. У цілому тенденція гуманізації становить характерну особливість сучасного етапу розвитку системи міжнародних відносин. За словами П. Циганкова, в міжнародно-політичній теорії гуманізація міжнародних відносин трактується як неухильне зростання впливу на цю сферу норм моралі і моральності, як іiі «олюднення», спрямована на визнання самоцінності людини, більш повне забезпечення його прав і свобод [7, с. 51].

Паралельно з ідеями глобального гуманізму сучасна парадигма міжнародних відносин обгрунтовує пріоритет демократії. Нині визнання в міжнародному співтоваристві залежить від ставлення до демократичних цінностей та принципів. Залишатися поза всесвітнього «демократичного клубу» в сучасному світі означає бути поза трендом. Це спонукає все нові і нові держави (в тому числі і Україну) орієнтуватися на демократичні цінності. У цьому контексті можна розглядати процес демократичних перетворень укінці $\mathrm{XX}$ ст. саме як тенденцію політичного розвитку світу, в реалізації якої дедалі важливішими виявляються не ендогенні 
(внутрішні) фактори (рівень соціально-економічного розвитку, політичні процеси в суспільстві і т. д.), а екзогенні по відношенню до даної державі, тобто міжнародне середовище. Саме вона спонукає до демократичних перетворень [1, с. 339].

Але, конфлікти постійно виникають у різних регіонах світу і вони змінюють свій зміст. Глобалізація супроводжується сплеском цілої низки конфліктів, які становлять нині одну 3 основних загроз як для національної, так і для міжнародної безпеки. Розвиток цивілізації й усвідомлення людством взаємозалежності і взаємопов'язаності сучасного світу не змогли викоренити війни і воєнні конфлікти як засіб силового вирішення міждержавних, релігійних, етнічних та інших протиріч. Вихід із конфліктних ситуацій за допомогою зброї, як не прикро це констатувати, залишається прикметною рисою сучасної епохи. Чи можливо взагалі спільне застосування дефініцій «війна», «демократія», «мораль», «право»?

Пошук відповіді на проблеми війни та миру, взаємозв'язку між демократією та миром триває i донині. Виникають різноманітні теорії стосовно збереження у сучасному глобалізаційному світі миру і як приклад, теорія демократичного миру (Democratic peace theory). Головна ідея теорії демократичного миру зводиться до твердження, що ліберальні демократії миролюбні за своєю природою і не воюють між собою, тому єдиний шлях до встановлення всезагального миру - це поширення ліберально-демократичних цінностей серед усіх країн світу. Ïї представники наполягають на тому, що принципи і методи здійснення політики всередині держави поширюються на іiі зовнішню політику, тому, на відміну від демократичних держав, авторитарні більш схильні до проявів насилля. Основні положення теорії демократичного миру вперше у систематичній формі викладені у статті М. Дойла «Кант, ліберальний спадок і міжнародні справи», де він доводить, що кантівський вічний мир може бути реалізованим тільки за умови домінування ліберальних цінностей, адже держави $з$ демократичним устроєм не зможуть самовільно вступати у війну, не маючи підтримки виборців, а останні, насамперед, не підтримають війну проти держави зі схожою системою цінностей. Крім того, громадяни демократичної держави зацікавлені в мирі і з економічної точки зору, маючи торгово-економічні взаємозв'язки 3 громадянами та організаціями іншої ліберально-демократичної держави [3, с. 278]. Необхідно зазначити і ще одного провідного автора теорії демократичного світу Брюса Рассета, який і зробив загальний висновок цієї теорії - демократії не воюють одна з одною.

Дійсно можна погодитися 3 цим висновком і сказати про те, що у демократичних країн $\epsilon$ причини уникати війн. По-перше, в контексті сучасної системи міжнародного права та колективної безпеки в Європі серед демократичних країн навряд чи виникнуть територіальні претензії і нині навіть важко уявити військовий конфлікт, наприклад, між Німеччиною і Францією 3 приводу Ельзас-Лотарингії. По-друге, демократичні держави - це зона індивідуального комфорту для всіх мешканців цих країн (так звана концепція «золотий мільярд»), тому якщо гіпотетично і можуть виникнути внутрішні конфлікти, то їх вирішують мирним шляхом у результаті переговорів. По-третє, це спільні інтереси, які як правило, стосуються спільної безпеки щодо єдиного чи однакового для цих країн потенційного зовнішнього ворога. У такому випадку, звичайно, союзні держави не будуть воювати одна з одною. Оскільки багато демократій уже мають спільні інтереси і об'єднуються, зокрема, в такі організації як НАТО або Європейський Союз (який об'єднав раніше конкуруючі та ворогуючі держави), то певно ж вони не воюватимуть між собою. Як ми бачимо, у демократичних країнах є багато причин стосовно спільного мирного існування. По-четверте, це багатство. Оскільки демократії, як правило, держави багаті, то тут важко визначити причинно-наслідковий механізм. Можна говорити про те, що для політично стабільної, економічно розвиненої держави економічно невигідно вести війну, то вони утримуються від таких методів розв'язання суперечностей.

Зазначимо, що представники теорії демократичного миру не виключать конфлікти, але тільки між демократіями і недемократіями. У цьому випадку є загроза військового конфлікту: «оскільки недемократії можуть використовувати силу чи погрози силою в конфліктах 3 іншими державами, а інші держави очікують такого варіанта, то це створює загрозу застосування сили у 
разі виникнення міжнародного конфлікту. Оскільки демократичні норми поведінки можуть бути легко використані опонентом - недемократичною державою, щоб уникнути відповідної реакції, демократичні держави повинні застосувати адекватні недемократичні методи в формуванні своїх відносин з недемократіями [4, с. 120]. Демократичні країни можуть не воювати одна з одною, але вони вимушено втягнуті в різні світові або регіональні конфлікти через те, що являються геополітичним суб' єктами і мають свої інтереси в різних регіонах. У зв'язку зі змінами правил гри на геополітичній шахівниці (не в останню чергу через агресивну політику Росії) демократичним країнам просто необхідно брати участь у цих процесах.

Необхідно звернути увагу, що за оцінками багатьох аналітиків, зокрема й 3. Бжезінського, на поч. XXI ст. світ увійшов у зону турбулентності, коли нестабільність та хаос лише посилюватимуться. Значні території потерпають від воєнних конфліктів, масових безладів, стихійних лих, посилюються техногенні ризики. Загострюються релігійні, світоглядні, етнічні, расові суперечності на фоні зростання потужності дії чинників, що їх посилюють [2, с. 3]. Насильство в сучасному світі не зникає, а набуває більш жорстоких і нелюдських форм. Війна органічно притаманна людини і позбавитися цього явища дуже нелегко, але $\epsilon$ можливість іi виправдання. Тому в теорії демократичного миру є теза, яка стверджує, що «...їхня миролюбність не поширюється на відносини з недемократичними державами, що демонструють на міжнародній арені політику сили і не здатні до раціональної дискусії та компромісів». Однак мир у справжньому сенсі цього слова неможливий, якщо в його основі лежить принцип сили, навіть якщо сила проявляється по відношенню до деяких держав. Отже, мир у рамках теорії справедливої війни розглядається як один зі способів морального виправдання війни, як іiі мета [3, с. 279]. Дійсно, можна зробити висновок, що війна в контексті демократичної парадигми може бути тільки справедливою.

Розробники теорії справедливої війни стверджують, що війни, які ведуться для самозахисту та визволення, і в яких дотримуються певних моральних обмежень, можуть визначатися як справедливі. Взагалі ідея «справедливої війни» завжди буде втілюватися в життя, поки існую конфлікти. Але війна завжди передбачає наявність моральних категорій, міркувань про те, справедлива війна або несправедлива, правильна чи неправильна. Однак введення в міжнародне право таких понять як «мораль» або «загальне благо», нерідко веде до сумних наслідків через неможливість розробити єдиний зміст цих категорій. Правові та моральні норми завжди були основними соціальними регуляторами суспільних відносин у демократичних країнах. У сфері міжнародних відносин вони мають свої суттєві особливості та відмінності. Дуже складною, наприклад, виглядає проблема моралі в міжнародних відносинах (і нема різниці між демократичними або недемократичними державами). Тут з'являється додаткова і не менше важка дилема: чи зобов'язаний міжнародний актор захищати інтереси особливої спільноти, до якої він належить (держава), або ж можна (і треба) пожертвувати ними заради блага більш широкої спільноті (етнічної, регіональної, загальнодемократичної, всесвітньої), за долю якої він також несе моральну відповідальність? Дійсно, як спростувати аргумент Н. Макіавеллі, який, допускаючи можливість моральної і обізнаної поведінки індивідів і соціальних груп у стабільному і процвітаючому суспільстві, наполягав на тому, що державний діяч, покликаний захищати спільні інтереси даного суспільства, не може виконати своє завдання, не вдаючись до брехні і обману, насильству і злу?

Зазначимо, що у пер. пол. XX ст. основні дискусії з приводу міжнародної справедливості відбувалися між політичними ідеалістами (прихильниками ідей I. Канта) та політичними реалістами (прихильниками ідей К. Шмідта), то в др. пол.-між розробниками проектів конституціоналізації та моралізації міжнародного права. Ю. Габермас стверджує, що нова дискусія розгорілася навколо проблеми «шляху досягнення миру і міжнародної безпеки, сприяння демократії і прав людини у всьому світі»: «Суперечка триває з приводу способу досягнення цих цілей: або вони мають бути досягнутими через юридично встановлені процедури демократичної... 
міжнародної організації, або ж - через односторонньо нав'язані рішення доброзичливого гегемона» $[6$, с. 8$]$.

Висновки. Теорія демократичного миру генетично пов'язана з ідеєю справедливої війни, оскільки апелює передусім до морального виправдання силових політичних дій. Війна - це явище, яке хронологічно пов'язана 3 появою перших людей. Але 3 виникненням сучасних демократій зміст і характер війни повинні змінитися в руслі основних постулатів демократії (свобода слова, захист прав особистості та ін.). У контексті цих процесів виникла теорія демократичного світу, яка гармонійно доповнює теорію справедливої війни. Необхідно звернути увагу, що рівень конфліктів не зменшується і демократичні країни теж втягнуті у військові регіональні конфлікти. Взагалі постбіполярний світ стає все більше багатогранним та складним для аналізу чи то з точки зору окремих концепцій в теорії міжнародних відносин, чи то з численних зовнішньополітичних доктрин, стратегій провідних учасників міжнародних відносин. Україна продемонструвала потужний рух до демократії, очищення від авторитаризму та корупції, з цієї причини у вирішенні української кризи США та ЄС змушені були зайняти проукраїнську позицію. Спрацював основний постулат теорії демократичного світу - «демократії не воюють».

\section{Список використаних джерел:}

1. Аманмырадов Н. А. Демократия и коллективная безопасность как принципы современной философии международных отношений / Н. А. Аманмырадов // Гілея: наук. вісн. 2014. - Вип. 90. - С. 339-342.

2. Єрмолаєв А. Український конфлікт і майбутнє світової та європейської безпеки [Електронний ресурс] / А. Єрмолаєв, С. Денисенко, О. Маркєєва, Л. Поляков // Нова Україна, Ін-т стратег. дослідж.

Режим доступу: http://newukraineinstitute.org/media/news/501/file/crisis security\%20UKR.pdf. - Назва 3 екрану. - Дата звернення 29.01.2017.

3. Панафідін I. О. Проблема миру в контексті філософської традиції справедливої війни / І. О. Панафідін // Гілея: наук. вісн. - 2014. - Вип. 80. - С. 276-279.

4. Ткаченко Ю. А. Теоретичні основи формування зовнішньої політики Заходу щодо нових незалежних держав / Ю. А. Ткаченко // Науковий вісник Дипломатичної академії України. - 2001. - Вип. 5. - С. 118-125.

5. Фукуяма Ф. Конец истории? / Ф. Фукуяма // Вопросы философии. - 1990. - № 3. C. $134-148$.

6. Хабермас Ю. Кантовский проект конституционализации международного права. Есть ли у него будущее? / Ю. Хабермас // Проблеми філософії права. - 2006-2007. - Т. IV/V. - С. 7-16.

7. Цыганков П. А. Гуманизация международных отношений: противоречия и парадоксы / П. А. Цыганков // Общественные науки и современность. - 1998. - № 1. - С. 51-59.

\section{References:}

1. Amanmyradov, N.A. (2014). Democracy and collective security as the principles of the modern philosophy of international relations. Hileia: naukovyi visnyk [Hileia: scientific bulletin], issue 90, pp. 339-342.

2. Yermolaiev, A. (2015). Ukrainian conflict and the future of world and European security. New Ukraine Institute for Strategic Studies. [online] Availiable at: http://newukraineinstitute.org/media/news/501/file/crisis_security\%20UKR.pdf [Accessed 29 January 2017]. Title from the screen.

3. Panafidin, I.O. (2014). The problem of peace in the context of the philosophical tradition of a just warHileia: naukovyi visnyk [Hileia: scientific bulletin], issue 80, pp. 276-279. 
4. Tkachenko, Yu. A. (2001). Theoretical basis for the formation of Western foreign policy towards the newly independent states. Naukovyi visnyk Dyplomatychnoi Akademii Ukrainy [Scientific Bulletin of the Diplomatic Academy of Ukraine], issue 5, pp. 18-125.

5. Fukuiama, F. (1990). The end of history? Voprosy filosofii [Questions of Philosophy], no. 3, pp. $134-148$.

6. Habermas, Ju. (2006-2007). Kantian project of constitutionalization of international law. Does he have a future? Problemi filosofii prava [Problems of the philosophy of law], Vol. IV/V, pp. 7-16.

7. Tcygankov, P.A. (1998). Humanization of international relations: contradictions and paradoxes. Obshchestvennye nauki i sovremennost [Social sciences and modernity], no. 1, pp. 51-59.

(С) Коротков Д. С., 2018 